\title{
IDEJNO RJEŠENJE OVJEŠENOG PJEŠAČKOG MOSTA
}

\section{Ivan Ćurić}

Sveučilište Josipa Jurja Strossmayera u Osijeku, Građevinski fakultet Osijek, student

\section{Marin Nikolić}

Sveučilište Josipa Jurja Strossmayera u Osijeku, Građevinski fakultet Osijek, student

Hrvoje Draganić

Sveučilište Josipa Jurja Strossmayera u Osijeku, Građevinski fakultet Osijek, asistent

\section{Ivan Kraus}

Sveučilište Josipa Jurja Strossmayera u Osijeku, Građevinski fakultet Osijek, asistent

Sažetak: Rad prikazuje idejno rješenje pješačkog mosta preko rijeke Drave u Osijeku. Širina vodene prepreke koju je potrebno premostiti iznosi 195,0 m. Odabrano rješenje je ovješeni armiranobetonski most $s$ jednim ekscentričnim kosim pilonom. Grafički prikaz mosta je izrađen u programskom paketu AutoCad, a numerički model mosta u programskom paketu SAP2000 v14.2. Na osnovi odabranih izmjera pojedinih dijelova konstrukcije, analize promjenjivog opterećenja prema EN1991-2 te odgovarajućih kombinacija opterećenja (EN1990), izvršena je modalna analiza i proračun odgovarajućih reznih sila mosta.

Ključne riječi: EN1990; EN1991-1-1; EN1991-2; ekscentrični kosi pilon; numerički model mosta; ovješeni most

\section{PRELIMINARY DESIGN OF CABLE-STAYED FOOTBRIDGE}

\begin{abstract}
This paper presents a preliminary design of a footbridge over the River Drava in Osijek. Width of the water obstacle is $195,0 \mathrm{~m}$. The selected solution is cable-stayed reinforced concrete bridge with an eccentric inclined pylon. Graphical drawings of the bridge were made in AutoCad software package and numerical model in the SAP2000 v14.2 software package. Modal analysis and calculation of the section forces was performed on the basis of selected dimensions of certain parts of the bridge structure, the analysis of variable loads according to EN1991-2 and the appropriate combination of loads according to EN1990.
\end{abstract}

Key words: EN1990; EN1991-1-1; EN1991-2; eccentric inclined pylon; numerical model; cable-stayed bridge; 


\section{Uvod}

U radu se daje prikaz idejnog rješenja pješačkog mosta preko rijeke Drave u Osijeku. Most je smješten u području Gornjeg grada, a predviđen je u produžetku Rokove ulice te bi na taj način povezao Gornji grad (desna obala grada) s Tvrđavicom (lijeva obala grada) Širina vodene prepreke koju je potrebno premostiti iznosi 195,0 m. Ukupna duljina rasponskog sklopa iznosi 181,0 m, dok je ukupna duljina konstrukcije 228,8 m (slika 1).

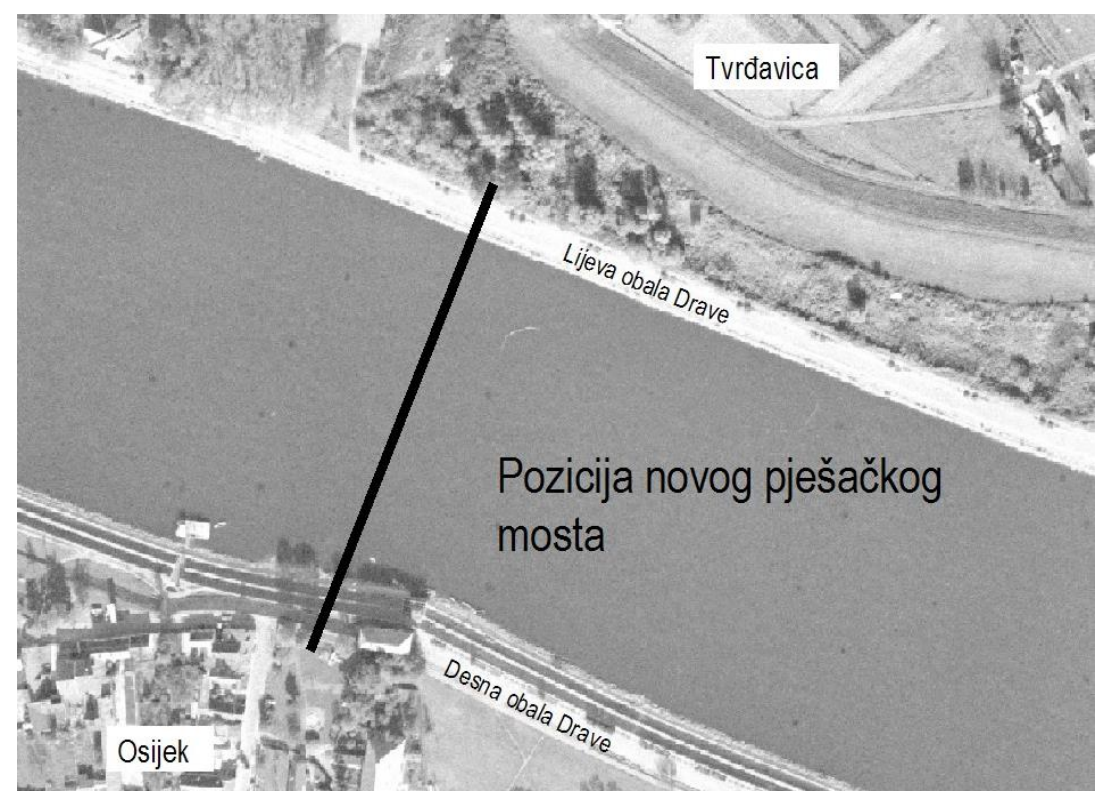

\section{Slika 1 - Pozicija novog pješačkog mosta}

Odabrano je rješenje ovješenog mosta s jednim ekscentričnim kosim masivnim armiranobetonskim pilonom. $\mathrm{Na}$ izbor ove vrste nosivog sustava usmjerila nas je estetska privlačnost ovakvih dosada izrađenih mostova. Sličan izvedeni most, koji nam je privukao pozornost i na temelju kojega se i razvila ideja o ovakvome obliku pješačkoga mosta, je most Erasmus u Rotterdamu, Nizozemska (slika 2).

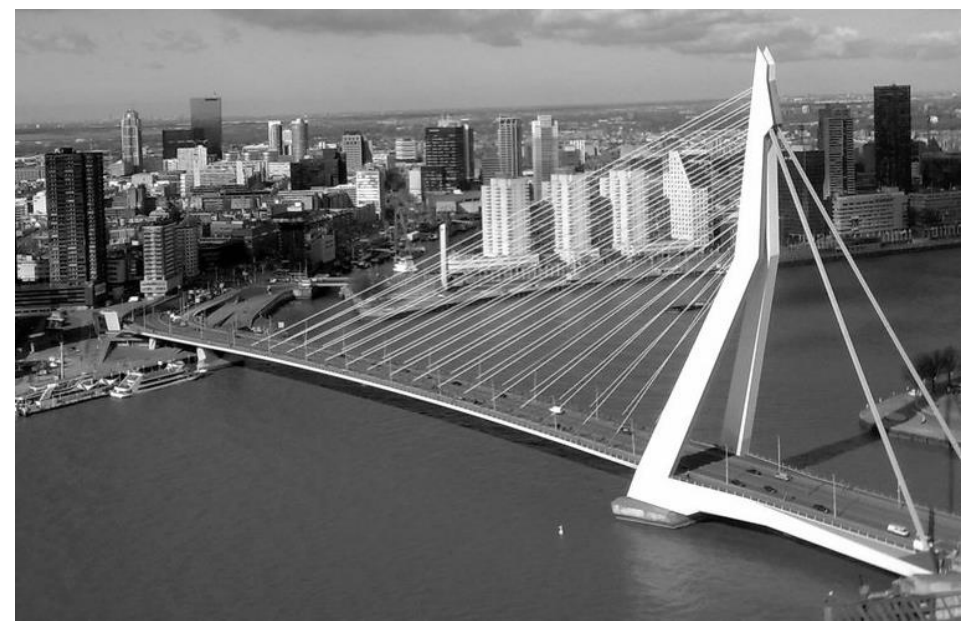

Slika 2 - Erasmus most u Rotterdamu, Nizozemska 
Ovješeni sklop čini armiranobetonska ploča ovješena kosim zategama od visokovrijednog čelika o ekscentrični masivni armiranobetonski pilon tipa "A“ (slika 3).

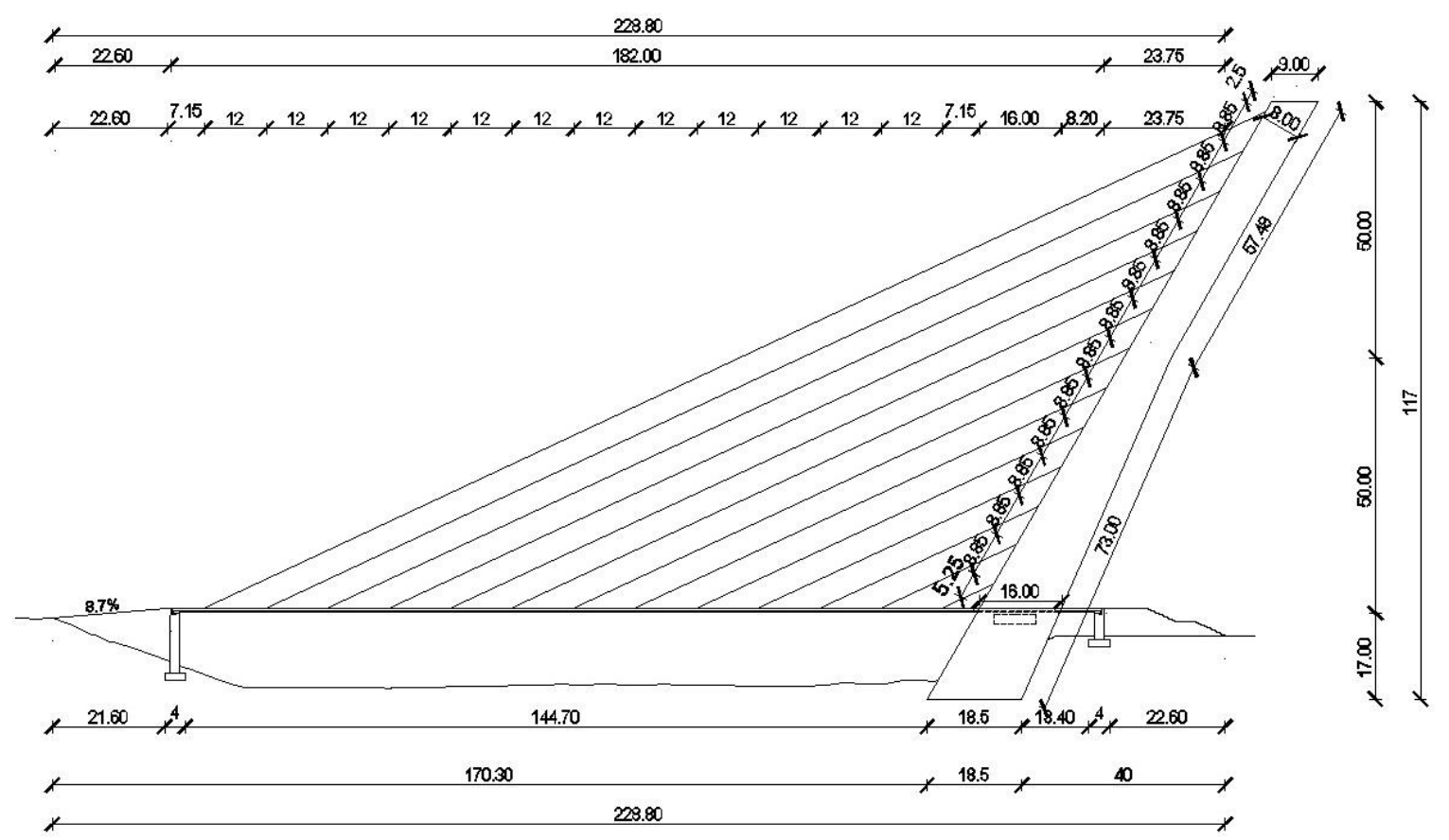

\section{Slika 3 - Uzdužni presjek}

Rasponski sklop čini armiranobetonska ploča i poprečni nosači na mjestima ovješenja. Širina ploče je 8,0 $m$, dok joj je poprečni presjek promjenjiv po visini, visina u polovini poprečnog presjeka je $0,43 \mathrm{~m}$, a na krajevima $0,38 \mathrm{~m}$. Korisna širina, širina za prometovanje pješaka je 6,9 m. Materijal od kojega je izvedena ploča je beton klase C35/45 i armatura B500B (slika 4).

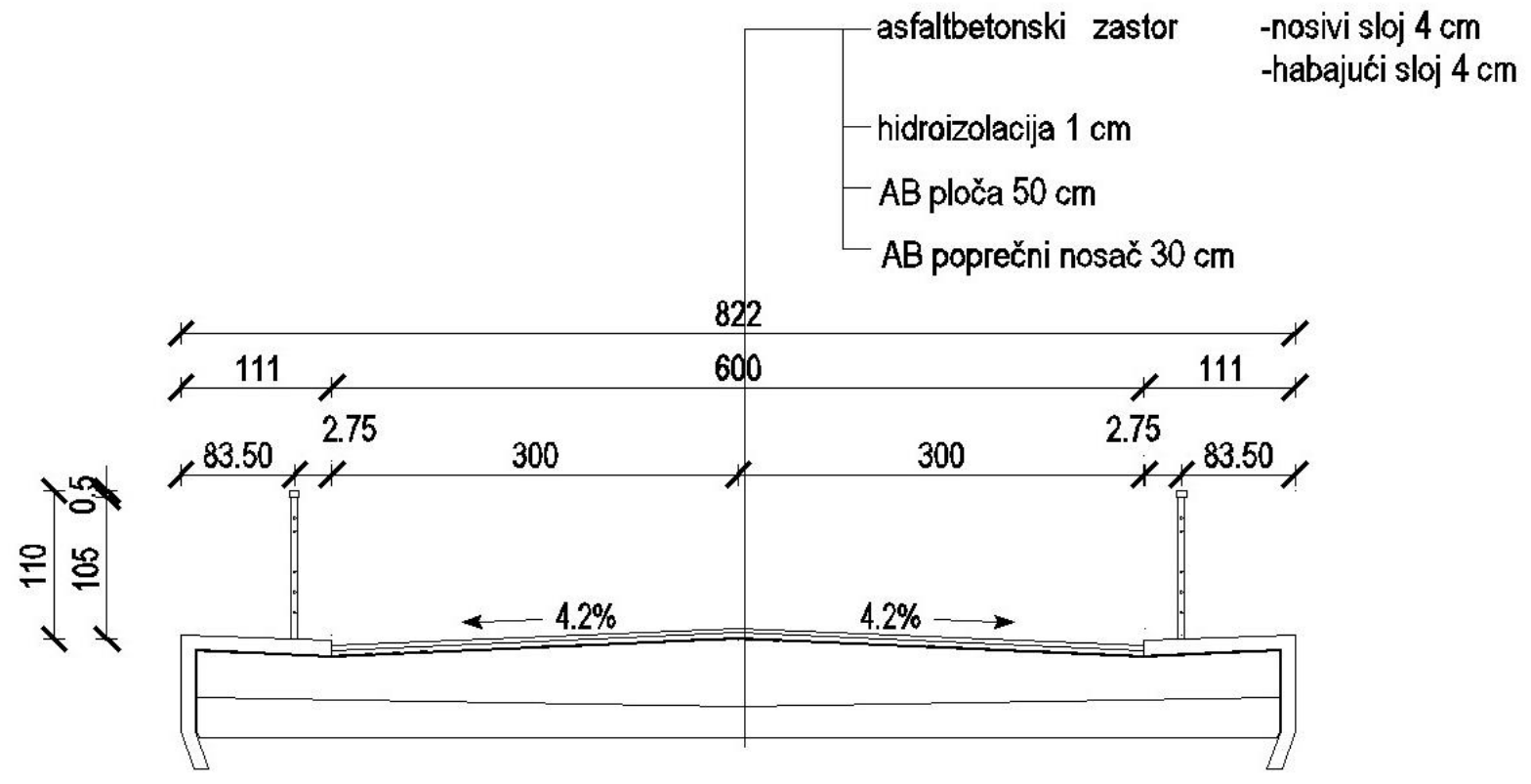

Slika 4 - Poprečni presjek u polju 
Pilon je armiranobetonski, punog poprečnog presjeka promjenjivog po visini, tipa „A“. Do 50,00 m ima dvostruki poprečni presjek, a na toj visini prelazi u jednostruki poprečni presjek. Ukupna visina pilona iznad temeljne ploče iznosi 117,00 m. Materijal od kojega je izveden pilon je beton klase C35/45 i armatura B500B (slika 5).

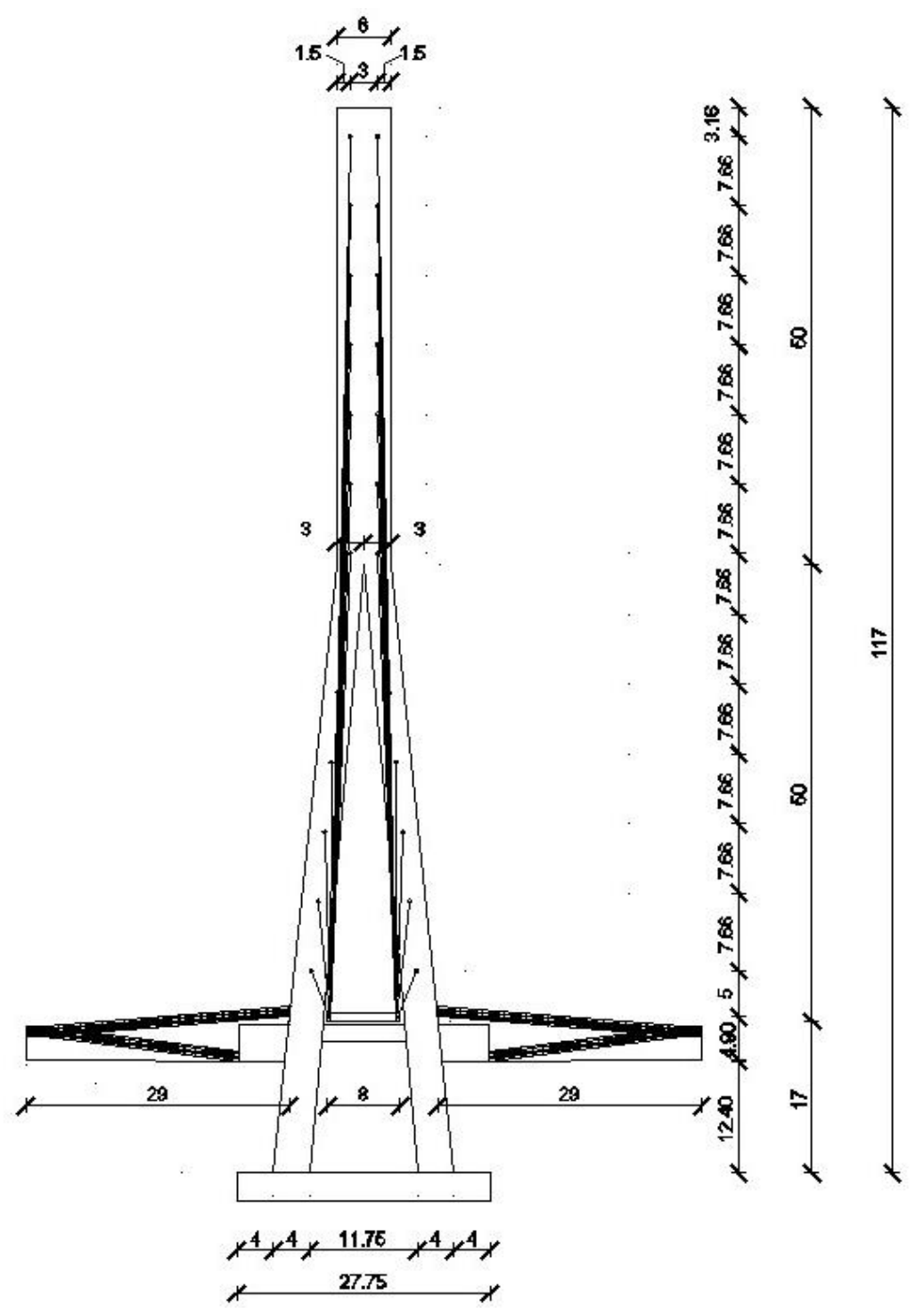

Slika 5 - Poprečni presjek kroz pilon

Vješaljke su raspoređene harfasto zbog olakšanog sidrenja i jednostavnije montaže. Primijenjen je tip tzv. parcijalnog ovješenja, tj. dolazi do prekida ovješenja na pilonu, armiranobetonska ploča se oslanja na poprečni nosač pilona, prečku. Ukupan broj vješaljki je 26 . Razmak između vješaljki na nosaču iznosi $12,00 \mathrm{~m}$, dok razmak između vješaljki na pilonu iznosi $8,85 \mathrm{~m}$. Na mjestima ovješenja vješaljke 0 armiranobetonsku ploču izrađeni su armiranobetonski poprečni nosači dimenzija $0,30 \times 0,50 \mathrm{~m}$. Nad upornjacima i nad poprečnom gredom pilona bit će postavljen po par elastomernih ležajeva, ukupno šest. Njihove dimenzije se su $30 \times 40 \mathrm{~cm}$ (slika 6). 


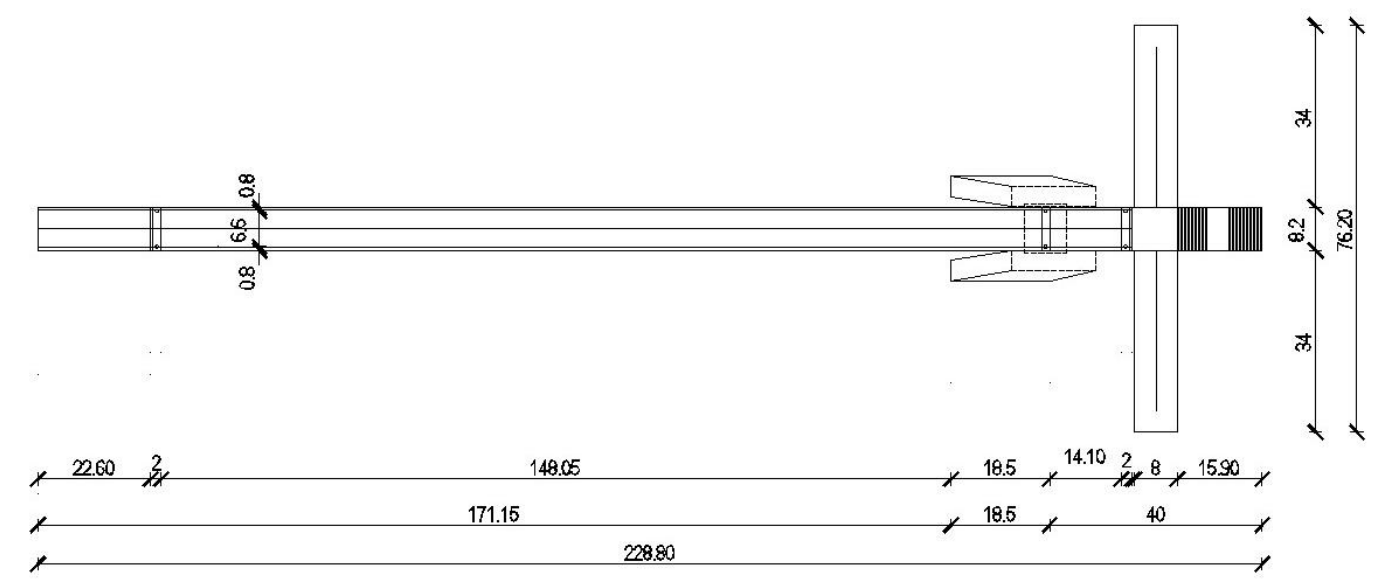

Slika 6 - Tlocrt

Rasponski sklop se na rubovima preko ležajeva oslanja na masivne upornjake. Širina zida upornjaka iznosi $7,50 \mathrm{~m}$, dok je visina upornjaka na lijevoj obali $6,50 \mathrm{~m}$, a na desnoj $10,00 \mathrm{~m}$. Krila upornjaka su paralelna $\mathrm{s}$ uzdužnom osi mosta, debljine 1,00 m. Upornjaci su izvedeni od betona klase C30/37 i armature B500B (slika $7 \mathrm{i}$ 8).

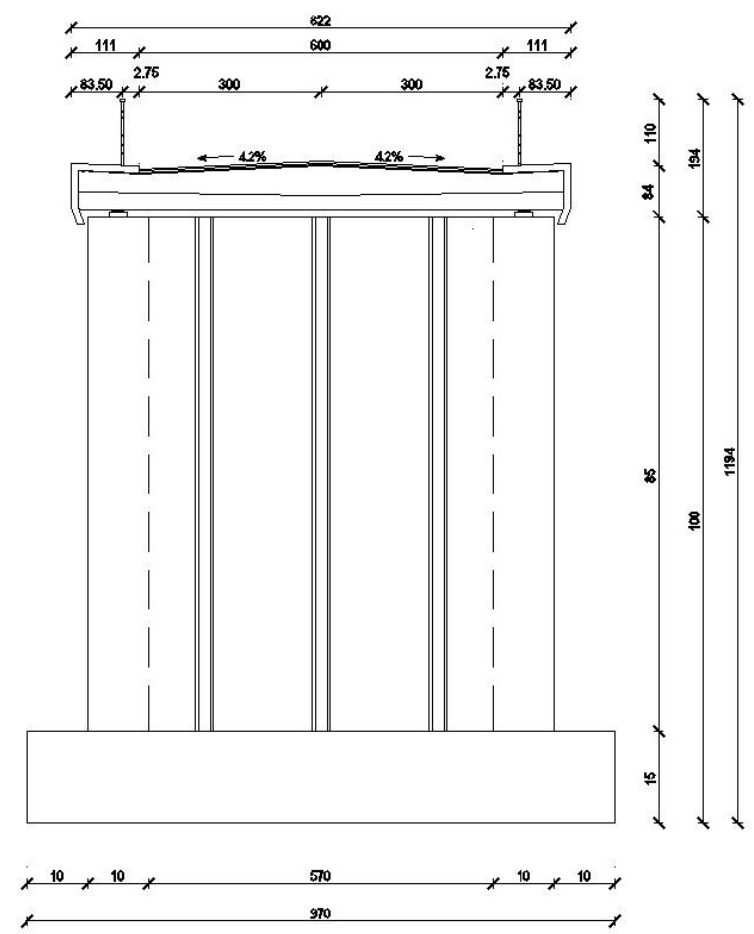

Slika 7 - Upornjak na desnoj obali Drave

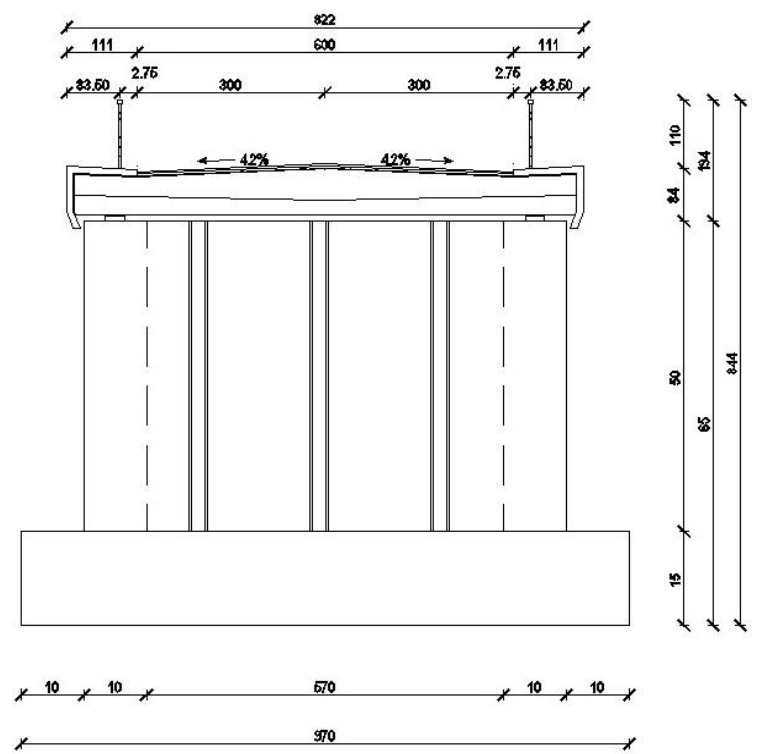

Slika 8 - Upornjak na lijevoj obali Drave

Prema projektu, na mostu je predviđena izvedba asfaltbetonske kolničke konstrukcije koja se sastoji od dva sloja, i to nosivog sloja $4 \mathrm{~cm}$ i habajućeg sloja $4 \mathrm{~cm}$. Hidroizolacija će biti izvedena po cijeloj širini armiranobetonske ploče od dva elementa: prvi je premaz dvokomponentnom epoksidnom smolom, dok je drugi jednoslojna bitumenska traka za varenje. Na mostu je postavljena metalna ograda za pješake ukupne visine $s$ rukohvatom 1,10 m (slika 4). Most je također opremljen dekorativnom rasvjetom. 


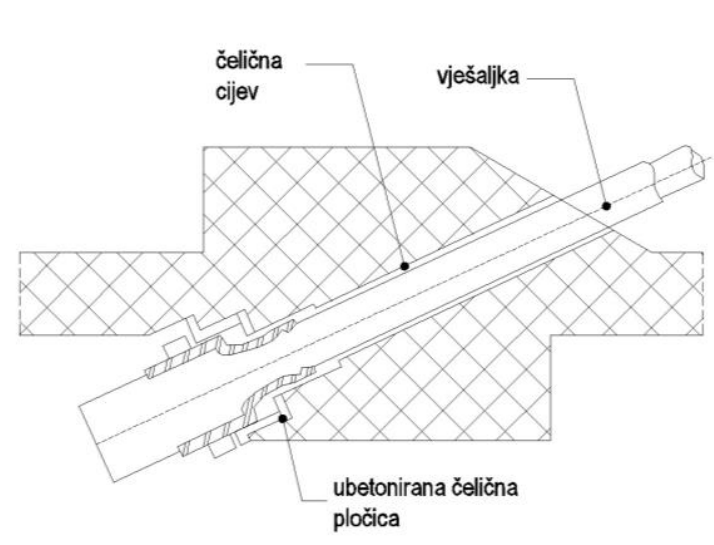

Slika 9 - Detalj sidrenja u ploču

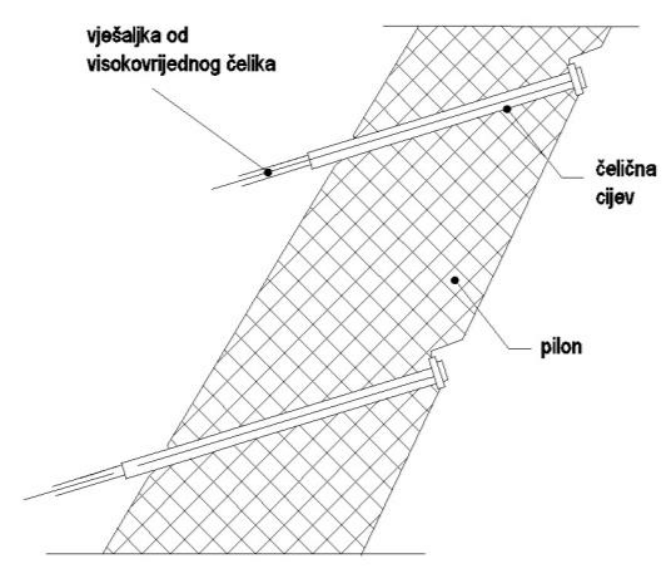

Slika 10 - Detalj sidrenja u pilon

Prilikom izvedbe spuštanja s razine mosta na razinu terena, na desnoj obali izvedena je kolnička konstrukcija s padom od $8,7 \%$, dok je na lijevoj obali veća visinska razlika pa je spuštanje na razinu šetnice izvedeno sustavom stepenica i rampi.

Proračun reznih sila je izveden prema euronormi primjenom programskog paketa SAP2000.

\section{Opterećenje mosta}

Pri analizi opterećenja za stalna djelovanja u obzir se uzimaju djelovanja od vlastite težine konstrukcije te asfaltbetonskog zastora, hidroizolacije, ograde te vijenca. Specifične težine korištene su iz EN 1991-1-1:2002 [1]. Za prometno opterećenje u obzir se uzima navala pješaka, Load Model 4 (Model opterećenja 4) te kao promjenjivo opterećenje temperatura (jednolika), snijeg, slijeganje temelja te potres kao izvanredno djelovanje. Vrijednosti navedenih opterećenja dobivene su prema EN1991-2:2002 [2] te EN1998-2:2002 [3].

Djelovanje vjetra nije uzeto u obzir jer se smatralo da zbog male težine rasponske konstrukcije te rasporeda vješaljki postoji dostatna torzijska krutost rasponskog sklopa na bočno djelovanje vjetra. Ovo treba provjeriti u glavnom projektu, te u slučaju značajnijih sila uzrokovanih djelovanjem vjetra prilagoditi poprečni presjek rasponskoga sklopa, odnosno učiniti ga aerodinamičnijim, što je znatno jeftinije od dodatnih pojačanja, ili povećati broj ili presjek vješaljki kako bi se povećala torzijska krutost mosta. Servisno vozilo nije uzeto u obzir jer se smatralo da samo opterećenje navalom pješaka pokriva ovo djelovanje, a u slučaju hitnog servisiranja mosta, most se zatvara za prometovanje pješaka. Međutim, ako proračun u glavnom projektu pokaže potrebu za servisnim vozilom kao opterećenjem na most, to možemo uzeti u obzir povećavanjem visine poprečnog presjeka rasponskog sklopa ili opet povećavanjem broja ili presjeka vješaljki.

\subsection{Potres}

Potresna zova: VIII => ubrzanje tla $a_{g}=2,0 \mathrm{~m} / \mathrm{s}^{2}$

Paramteri tla:

- kategorija tla B, tip spektra 1

- prigušenje konstrukcije $5 \%$

- faktor ponašanja $q=2,0$ 
SPEKTRI (slika 11 i 12)

a) horizontalni smjer

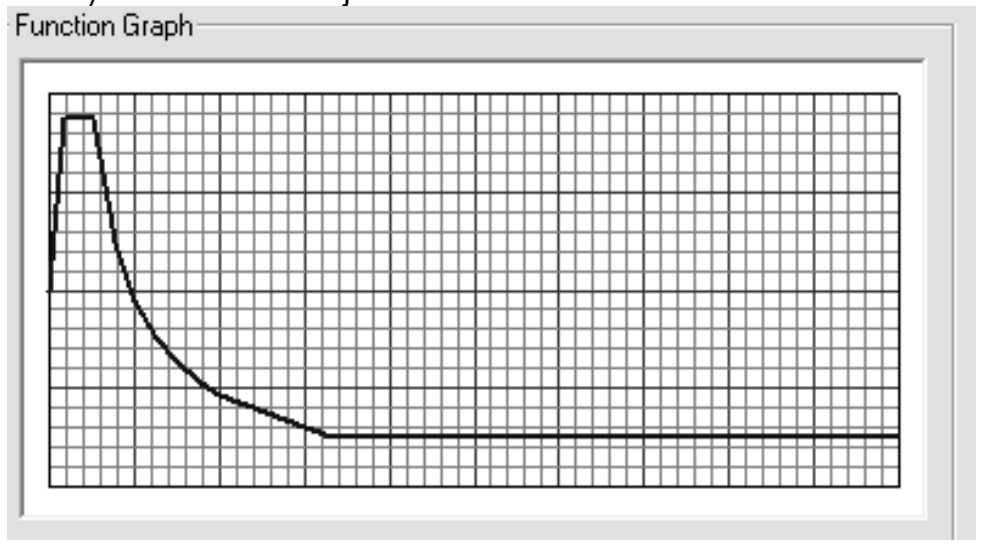

$$
\begin{aligned}
& T_{b}=0,15 \mathrm{~s} \\
& T_{c}=0,50 \mathrm{~s} \\
& T_{b}=2,00 \mathrm{~s}
\end{aligned}
$$

\section{Slika 11 - Spektar potresa za horizontalni smjer}

b) vertikalni smjer

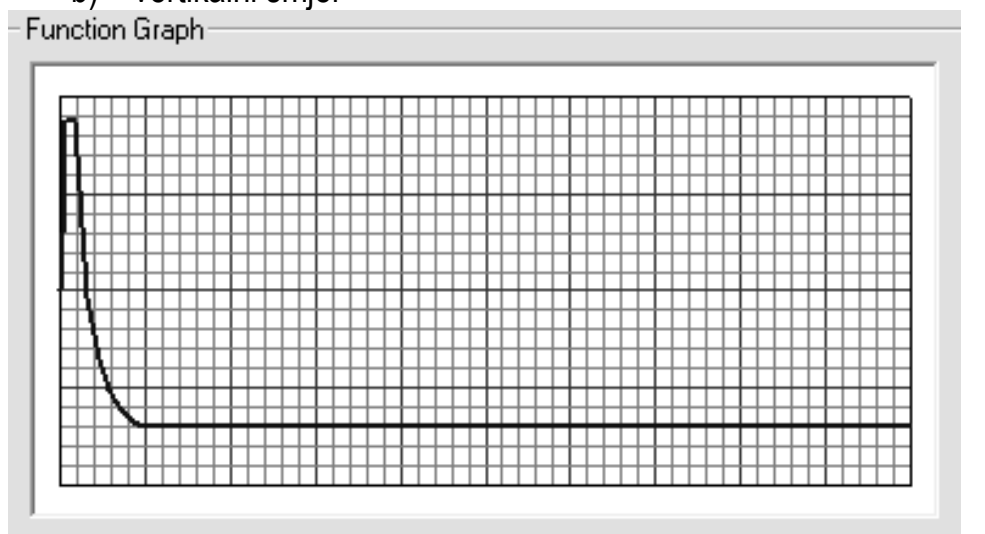

$$
\begin{gathered}
T_{b}=0,05 \mathrm{~s} \\
T_{c}=0,15 \mathrm{~s} \\
T_{d}=1,00 \mathrm{~s} \\
S_{d}\left(T_{b}\right)=0,225 \\
S_{d}\left(T_{b}\right)=0,225 \\
S_{d}\left(T_{d}\right)=0,036
\end{gathered}
$$

\section{Slika 12 - Spektar potresa za vertikalni smjer}

\section{Kombinacije opterećenja}

Izrađeno je ukupno 25 osnovnih te seizmička kombinacija djelovanja. Prilikom izrade kombinacija djelovanja korišteno je stalno opterećenje, promjenjivo opterećenje, slijeganje oslonaca, temperatura, snijeg te potresno opterećenje definirano spektrom odgovora za horizontalni i vertikalni smjer. Kombinacije djelovanja određene su prema [4]. Za osnovnu kombinaciju opterećenja definiran je izraz:

$$
\sum \gamma_{G, j} G_{k, j}+\gamma_{Q, 1} Q_{k, 1}+\sum \gamma_{Q, i} \psi_{0, i} Q_{k, i}
$$

gdje je:

$\gamma_{G}-$ parcijalni faktor sigurnosti za stalno opterećenje $\left(\gamma_{G}=1,35\right)$

$G_{k}-$ karakteristična vrijednost stalnog opterećenja

$Y_{Q}-$ parcijalni faktor sigurnosti za korisno opterećenje $\left(\gamma_{Q}=1,50\right)$

$Q_{k}-$ karakteristična vrijednost korisnog opterećenja 
$\psi_{0, i}-$ koeficijent kombinacije za korisno opterećenje $\left(\psi_{0, \mathrm{i}}=0,5 ; 0,6 ; 0,7\right)$,

a za uvrštene vrijednosti parcijalnih faktora izraz (1) postaje:

$$
1,35 \times G+1,50 \times Q+1,5 \times 0,6 \times T+1,5 \times 0,5 \times S n+1,5 \times 0,7 \times S_{L}
$$

gdje je:

$T$ - djelovanje temperature

$S_{n}$ - djelovanje snijega

$S_{L}-$ slijeganje temelja.

Za seizmičku kombinaciju korišten je izraz:

$$
\begin{aligned}
& \sum G_{k, j}+A_{E d}+\sum \psi_{2, i} Q_{k, i} \\
& 1,00 \times G+0,30 \times Q+1,00 \times A_{E d}
\end{aligned}
$$

gdje je:

$G$ - stalno opterećenja

$Q$ - korisno opterećenje

$A_{E d}-$ proračunska vrijednost potresnog opterećenja.

\section{Model mosta}

U programskom paketu AutoCad napravljeni su osnovni crteži te kasnije razrađeni detalji. Radi simuliranja ponašanja konstrukcije u stvarnom okolišu, most je modeliran u programskom paketu SAP2000 te opterećen na način koji bi što približnije simulirao stvarno opterećenje u okolišu pri uporabi. Most je načinjen od 3 osnovna dijela: pločasti nosač s poprečnim grednim nosačima u točkama ovješenja (slika 13), kosi pilon promjenjivog poprečnog presjeka (slika 14) i vješaljke.

Budući da je pilon nagnut i promjenjivog poprečnog presjeka po visini, modeliranje istoga je bilo prilično komplicirano. Da bi se odredili čvorovi osi pilona, iz AutoCad-a su očitane njihove koordinate te ucrtane u SAP2000 [4]. Površine poprečnih presjeka pilona definirane su u čvorovima ovješenja. Postoji ukupno 11 presjeka pomoću kojih su definirani neprizmatični poprečni presjeci (eng. Non prismatic section) [5] da bi se dobila promjenjiva debljina pilona po visini. Čvorovi sidrenja vješaljki se ne nalaze na osi pilona, već su izmješteni lijevo i desno od osi pilona, tj. čvorovi sidrenja imaju koordinate deinirane prema nacrtima u AutoCAD-u. Kako bi se dobio kompaktan sklop, čvor osi pilona te čvorovi sidrenja vješaljki, definirani na istoj visini, povezani su krutom vezom (eng. Rigid link) [6]. Pilon i poprečni nosači modelirani su kao štapni elementi (eng. Frame elements), što znači kako se u elementu, osim uzdužne sile, pojavljuju momenti savijanja i poprečne sile. Vješaljke su modelirane kao užad (eng. Cable elements), što znači da se u njima javlja samo uzdužna sila.

Ploča rasponskog sklopa se, okomito na protezanje osi mosta, sastoji od 4 plošna elementa. Plošnim elementima se, od osi mosta prema njegovom rubu, debljina linearno smanjuje s $43 \mathrm{~cm}$ na $38 \mathrm{~cm}$. Ploča je modelirana pomoću tankih ljuskastih elemenata (eng. Shell thin) [7]. Elementi su homogeni te kombiniraju neovisno ponašanje membrane i ploče. Kako je odabrana tanka ljuska, korištena je Kirchhoff-a formulacija koja zanemaruje poprečne posmične deformacije. Tanka ljuska koristi 4-čvorni četverostrani konačni element. Dodatna podjela ploče radi postizanja točnijih rezultata nije rađena zbog velikog obima proračuna. U točkama ovješenja postavljeni su poprečni nosači da bi se smanjili utjecaji velikih koncentriranih sila. Poprečni nosači su s pločom povezani u točkama pomoću krute veze.

Vješaljke su načinjene od visokovrijednog čelika s granicom popuštanja od $1800 \mathrm{~N} / \mathrm{mm}^{2}$, te ugrađene s početnom silom da bi se izbjegle velike vibracije istih. Sam poprečni presjek vješaljki definiran je kao puni kružni presjek, promjera $17,5 \mathrm{~cm}$. 
Opterećenja koja su još nanesena su i slijeganje oslonaca, temperatura, snijeg te navala pješaka. Seizmičko opterećenje je definirano kroz spektralnu analizu, koristeći predefinirani spektar prema euronormi, s prethodno određenim parametrima.

\subsection{Numerički elementi mosta}

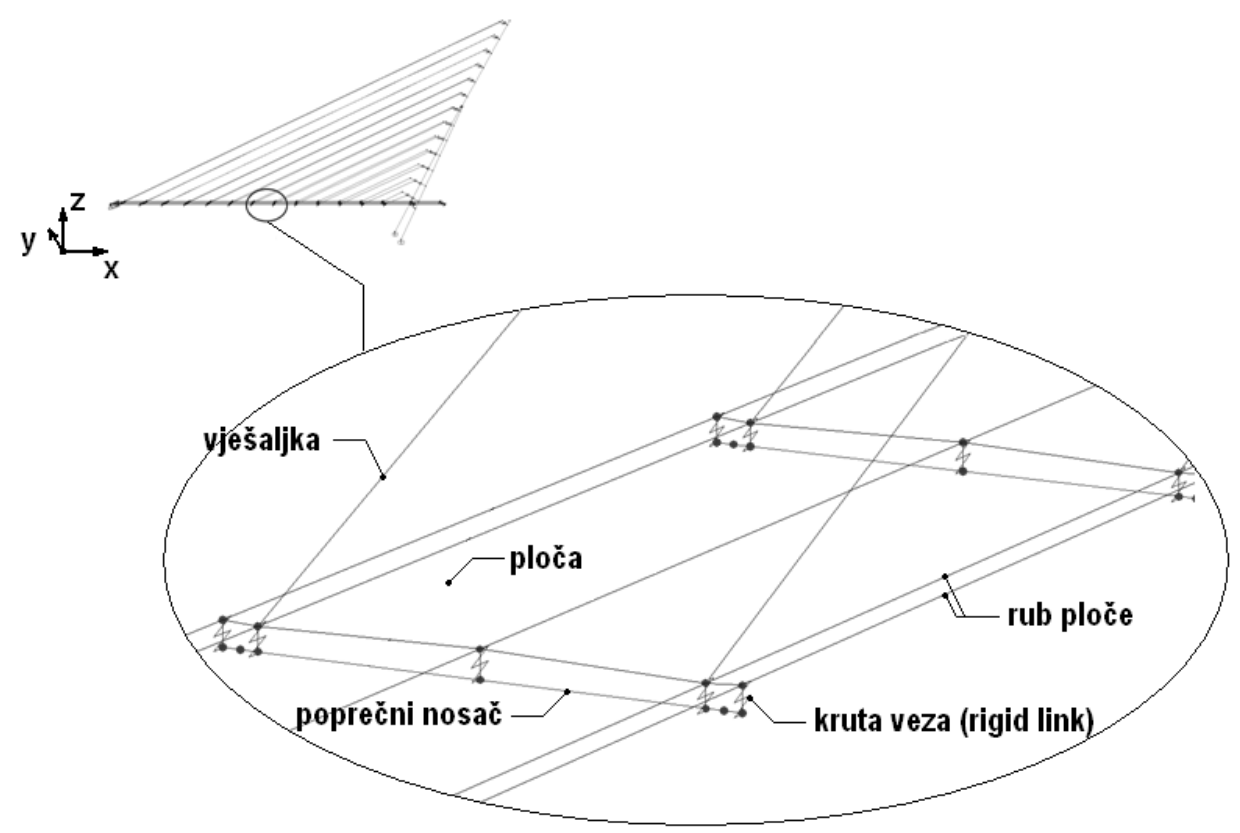

Slika 13 - Štapni model mosta 


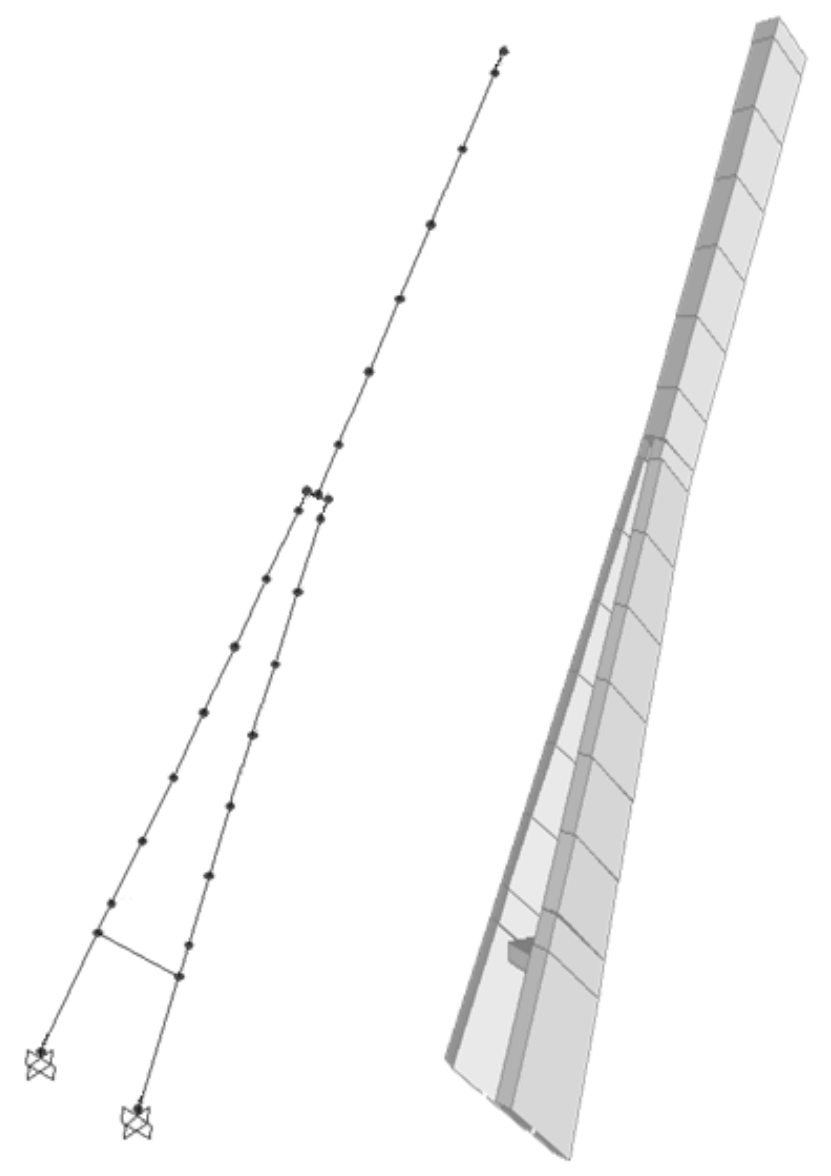

\section{Rezultati proračuna}

\section{Slika 14 - Model pilona}

\subsection{Modalna analiza}

Dominantni vlastiti oblici po smjerovima su dani u tablici 1.

\section{Tablica 1 - Dominantni vlastiti oblici}

\begin{tabular}{|c|c|c|c|}
\hline Smjer & Vlastiti oblik & \% pobuđene mase & $T[\mathbf{s}]$ \\
\hline UX & 1. & 21,25 & 1,836 \\
\hline UY & 5. & 46,69 & 0,885 \\
\hline UZ & 43. & 51,37 & 0,116 \\
\hline
\end{tabular}

Pri analizi se koristilo ukupno 50 vlastitih oblika te se uspjelo pobuditi $\mathbf{9 9 , 9 7 \%}$ mase za smjer $X, \mathbf{9 9 , 9 9 \%}$ mase za smjer $Y$, te $99,74 \%$ mase za smjer Z. Slike 15 do 20 prikazuju prvih šest vlastitih oblika mosta. 


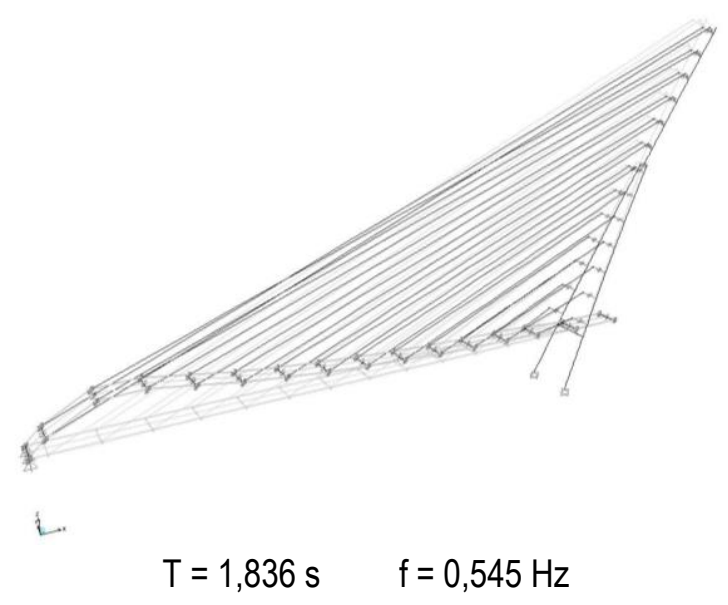

Slika 15 - Vlastiti oblik 1.

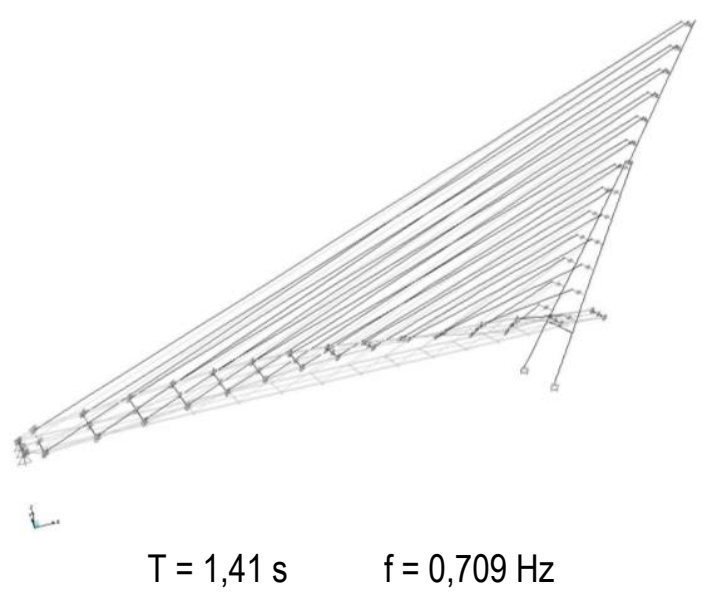

Slika 17 - Vlastiti oblik 3.

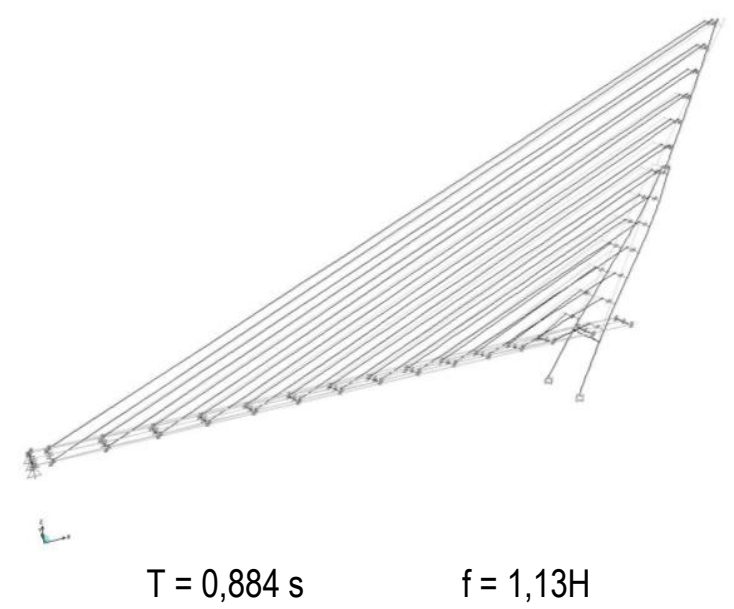

Slika 19 - Vlastiti oblik 5.

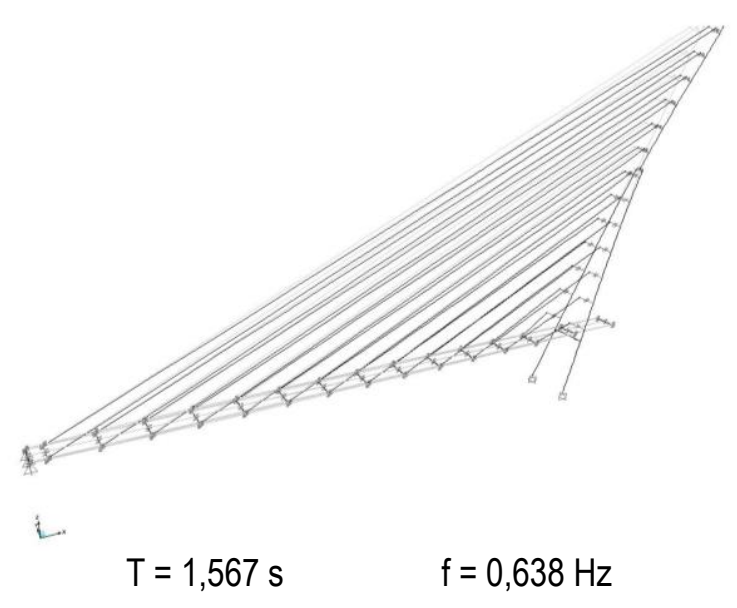

Slika 16 - Vlastiti oblik 2.

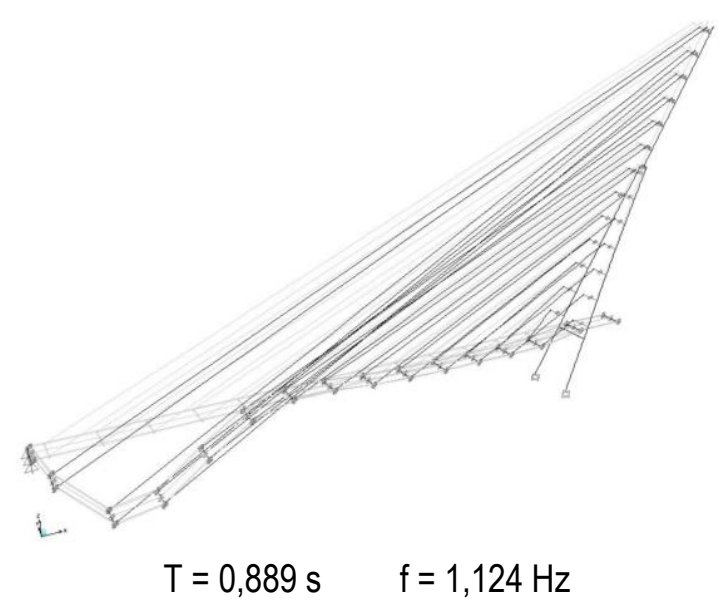

Slika 18 - Vlastiti oblik 4.

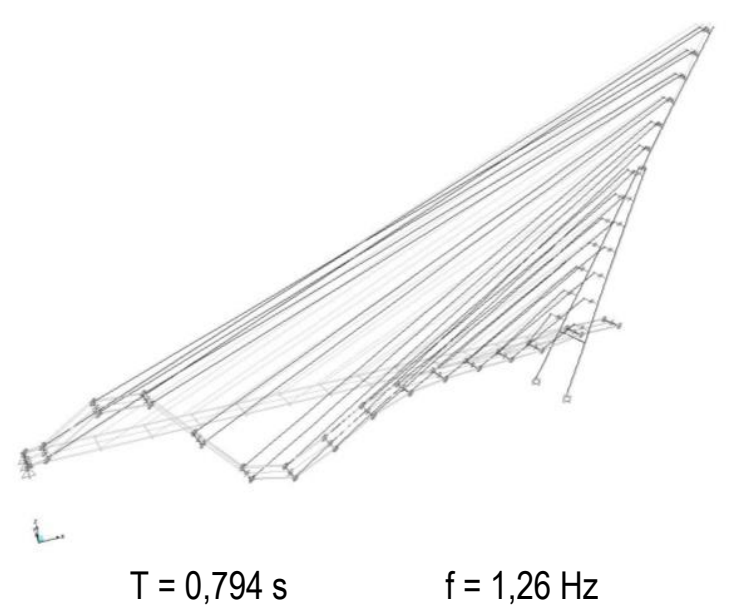

Slika 20 - Vlastiti oblik 6. 


\subsection{Rezne sile}

\subsubsection{Statička analiza}

Tablica 2 prikazuje rezne sile u konstrukcijskim elementima ovješenoga mosta dobivene statičkom numeričkom analizom u programskom paketu SAP2000.

Tablica 2 - Rezne sile dobivene statičkom analizom

\begin{tabular}{c|ccc}
\hline konstrukcijski element & $\mathrm{N}$ & $\mathrm{M}$ & $\mathrm{V}$ \\
{$[\mathrm{kN}]$} & {$[\mathrm{kNm}]$} & - \\
\hline Vješaljke & 3471,50 (vlak) & - & - \\
Ploča & $>10000 / \mathrm{m}^{*}$ & - & - \\
Stupovi & 174520 (tlak) & 4611,87 & 37000 \\
Reakcije & 176670 & 1702260 & - \\
\hline
\end{tabular}

\subsubsection{Spektralna analiza}

Tablica 3 prikazuje rezne sile u konstrukcijskim elementima ovješenoga mosta dobivene spektralnom numeričkom analizom u programskom paketu SAP2000.

Tablica 3 - Rezne sile dobivene spektralnom analizom

\begin{tabular}{c|ccc}
\hline konstrukcijski element & $\mathrm{N}$ & $\mathrm{M}$ & $\mathrm{V}$ \\
{$[\mathrm{kN}]$} & {$[\mathrm{kNm}]$} & {$[\mathrm{kN}]$} \\
\hline Vješaljke & 2431,94 (vlak) & - & - \\
Ploča & $>4000 / \mathrm{m}^{*}$ & - & - \\
Stupovi & 129830 (tlak) & 5093,30 & - \\
Reakcije & 129890 & 1618500 & 22810 \\
\hline
\end{tabular}

\footnotetext{
*zbog limitiranosti u tehničkom pogledu te sukladno tome sporosti procesa analize, u programskom paketu SAP2000 rabljena je dosta gruba podjela pločastih elemenata
}

\subsection{Pomaci}

\subsubsection{Pomaci pri statičkoj analizi}

Tablica 4 prikazuje apsolutne pomake u pojedinom smjeru konstrukcijskih elemenata ovješenoga mosta dobivene statičkom numeričkom analizom u programskom paketu SAP2000.

Tablica 4 - Apsolutni pomaci dobiveni statičkom analizom

\begin{tabular}{c|ccc}
\hline konstrukcijski element & $\begin{array}{c}\mathrm{x} \\
{[\mathrm{m}]}\end{array}$ & $\begin{array}{c}\mathrm{y} \\
{[\mathrm{m}]}\end{array}$ & $\begin{array}{c}\mathrm{z} \\
{[\mathrm{m}]}\end{array}$ \\
\hline Ploča & 0,046 & 0,002 & 0,404 \\
Pilon & 0,285 & 0,165 & - \\
\hline
\end{tabular}




\subsubsection{Pomaci pri spektralnoj analizi}

Tablica 5 prikazuje apsolutne pomake u pojedinom smjeru konstrukcijskih elemenata ovješenoga mosta dobivene spektralnom numeričkom analizom u programskom paketu SAP2000.

Tablica 5 - Apsolutni pomaci dobiveni spektralnom analizom

\begin{tabular}{c|ccc}
\hline konstrukcijski element & $\mathrm{x}$ & $\mathrm{y}$ & $\mathrm{z}$ \\
\hline Ploča & {$[\mathrm{m}]$} & {$[\mathrm{m}]$} & {$[\mathrm{m}]$} \\
\hline Pilon & 0,017 & 0,006 & 0,10 \\
& 0,24 & 0,01 & 0,14 \\
\hline
\end{tabular}

\section{Zaključak}

U članku se prikazuje idejno rješenje ovješenog pješačkog mosta s jednim ekscentrično postavljenim masivnim pilonom. Rad daje preliminarne crteže konstrukcije mosta te numerički model mosta i preliminarni izračun reznih sila za daljnje dimenzioniranje. Izvedba ovakvih vrsta nosivih sustava mostova u raznim varijantama uzima sve više prostora, ponajprije zbog svoje estetske prihvatljivosti, iako je proračun i izvedba takvih konstrukcija izrazito složena. Analizom mosta utvrđeno je kako najveći problem za stabilnost mosta predstavlja ponašanje vješaljki zbog mogućnosti njihovih prekomjernih pomaka i vibracija. Problem prekomjernih pomaka može se riješiti postavljanjem većeg broja vješaljki pomoću čega dobivamo znatno kruću konstrukciju, a problem prekomjernih vibracija postavljanjem prigušivača na vješaljke. Već pri izradi projekta uočena je velika cijena izvedbe ovakve vrste konstrukcije, koja je ponajprije posljedica velikog utroška materijala te izrazito složenog načina gradnje ekscentričnog kosog pilona. Uz veliku cijenu izgradnje ovog tipa mostova, unatoč svim prednostima koje ima nad ostalim oblicima s estetskog stajališta, još jedan od razloga što se ovaj tip mostova u svijetu rijetko izvodi je vrlo velika složenost proračuna, pa se u konačnici na projektiranje i gradnju ovakvih i sličnih mostova upuštaju samo „hrabri“ projektanti i izvođači kojih je u svijetu, okrenutome novčanom profitu, sve manje i manje.

\section{Literatura}

[1] CEN - European Committee for Standardization, 2002. Eurocode 1 - Actions on structures - Part 1-1: General actions - Densities, self-weight, imposed loads for buildings

[2] CEN - European Committee for Standardization, 2002. Eurocode 1 - Actions on structures- Part 2 - Traffic loads on bridges

[3] CEN - European Committee for Standardization, 2002. Eurocode 8 - Design of structures for earthquake resistance - Part 2: Bridges

[4] CEN - European Committee for Standardization, 2001. Eurocode 0 - Basis of structural design

[5] http://www.kxcad.net/Computers Structures Inc/SAP2000 V11/SAP2000/menus/draw/ draw_special_joint.htm

[6] http://www.kxcad.net/Computers_Structures_Inc/SAP2000_V11/SAP2000/menus/define/frame_sections/ nonprismatic.htm

[7] http://www.kxcad.net/Computers_Structures_Inc/SAP2000_V11/SAP2000/menus/draw/ draw_1_joint_link.htm

[8] http://www.kxcad.net/Computers_Structures_Inc/SAP2000_V11/SAP2000/menus/define/area_sections/ define_area_sections.htm

[9] www.kxcad.net/Computers_Structures_Inc/SAP2000_V11/SAP2000/menus/define/functions/ response_spectrum/define_response_spectrum_functions.htm 